\title{
Anaerobic Methane Oxidation in a Landfill-Leachate Plume
}

\author{
ETHAN L. GROSSMAN,*, \\ LUIS A. CIFUENTES, $\neq A N D$ \\ ISABELLE M. COZZARELLI§
}

Department of Geology \& Geophysics and

Department of Oceanography, Texas A\&M University, College Station, Texas 77843, and U.S. Geological Survey, 431 National Center, Reston, Virginia 20192

The alluvial aquifer adjacent to Norman Landfill, OK, provides an excellent natural laboratory for the study of anaerobic processes impacting landfill-leachate contaminated aquifers. We collected groundwaters from a transect of seven multilevel wells ranging in depth from 1.3 to $11 \mathrm{~m}$ that were oriented parallel to the flow path. The center of the leachate plume was characterized by (1) high alkalinity and elevated concentrations of total dissolved organic carbon, reduced iron, and methane, and (2) negligible oxygen, nitrate, and sulfate concentrations. M ethane concentrations and stable carbon isotope $\left(\delta^{13} \mathrm{C}\right)$ values suggest anaerobic methane oxidation was occurring within the plume and at its margins. Methane $\delta^{13} \mathrm{C}$ values increased from about $-54 \%$ near the source to $>-10 \%$ downgradient and at the plume margins. The isotopic fractionation associated with this methane oxidation was $-13.6 \pm 1.0 \%$. Methane ${ }^{13} \mathrm{C}$ enrichment indicated that $80-90 \%$ of the original landfill methane was oxidized over the $210-\mathrm{m}$ transect. Firstorder rate constants ranged from 0.06 to 0.23 per year, and oxidation rates ranged from 18 to $230 \mu \mathrm{M} / \mathrm{y}$. Overall, hydrochemical data suggest that a sulfate reducermethanogen consortium may mediate this methane oxidation. These results demonstrate that natural attenuation through anaerobic methane oxidation can be an important sink for landfill methane in aquifer systems.

\section{Introduction}

Municipal landfills contribute greenhouse gases to the atmosphere, and older landfills can threaten local water quality. In 1997 there were about 2500 landfills operating in the U.S., down from nearly 8000 in 1988 (1). Although the number of operating landfills is decreasing, the number of closed landfills is increasing, posing a continued risk of leachate contamination into underlying aquifers. Landfills are the U.S.'s largest anthropogenic source of methane emissions (2). Numerous studies have examined natural attenuation of landfill methane through aerobic oxidation in landfill cover soils (e.g., refs 3 and 4), but few have examined attenuation of the landfill methane that contaminates groundwater. Moreover, few studies have had theopportunity to investigate the basic process of anaerobic methane oxidation in an aquifer setting. The alluvial aquifer adjacent

* Correspondingauthor phone: (979)845-0637; fax: (979)845-6162; e-mail: e-grossman@amu.edu.

† Department of Geology \& Geophysics, Texas A\&M University.

‡ Department of Oceanography, Texas A\&M University.

$\S$ U.S. Geological Survey. to Norman Landfill in Oklahoma provides an excellent natural laboratory for the study of anaerobic methane oxidation in landfill-leachate plumes.

Several comprehensive studies have characterized the anaerobic environments of landfill-leachate plumes (e.g., refs 5-8). The abundance of electron donors in landfill-leachate plumes results in a paucity of electron acceptors. Ideally, methanogenesis dominates closest to the landfill sourceand is followed sequentially downgradient by sulfate reduction, iron reduction, nitrate reduction, and oxygen reduction. In reality, these processes can overlap and exhibit a complex distribution pattern reflecting the heterogeneity of theaquifer. Thedistribution of redoxenvironments will havea profound effect on the degradation of dissolved organic compounds. At the Vejen and Grindsted landfills in Denmark, scientists observed nearly completenatural attenuation of nonvolatile dissolved organic carbon (NVDOC) and specific volatile organic compounds in the anaerobic portion of the plume $(9,10)$. Methane in the Grindsted landfill plume disappeared in the nitrate zone, leading Bjerg et al. (11) to suggest that methane could be an electron donor for nitrate reduction. Methane oxidation by nitrate reduction in aquifers was previously demonstrated with natural-gradient tracer tests (12). Methane oxidation in association with sulfate reduction has been proposed to explain changes in groundwater chemistry resulting from natural processes (13) and a gas well blow-out (14).

Stable isotopes have been widely used as tracers for methaneoxidation $(13,15,16)$. Microorganisms preferentially consume ${ }^{12} \mathrm{CH}_{4}$, resulting in ${ }^{13} \mathrm{C}$ depletion in the $\mathrm{CO}_{2}$ produced and ${ }^{13} \mathrm{C}$ enrichment in theresidual methane(17-19). Previous studies haveused stablecarbon isotopes as a tracer for aerobic methane oxidation in landfill soils and have estimated that $24-46 \%$ of methane is oxidized during transport through the landfill cover $(20,21)$. We have used carbon isotopic measurements to estimate the fraction and rate of methane oxidized in an anaerobic leachate plume. These results demonstrate that anaerobic methane oxidation can be an important methane sink in contaminated aquifers.

\section{Study Area and Methods}

Site History and Hydrogeology. The Norman Landfill Research Site is located on the Canadian River alluvial plain in central Oklahoma (Figure 1). The landfill accepted unrestricted solid waste from the city of Norman from 1922 to 1985 . Waste was dumped into trenches about $3 \mathrm{~m}$ deep and covered with $0.15 \mathrm{~m}$ of sand. In 1985, the landfill was closed and covered with a vegetated earthen cap made of local clay and silty-sand material. The landfill never utilized liners or leachatecollection systems. Consequently, aleachate plume developed that extends at least $225 \mathrm{~m}$ from the edge of thelandfill (22). In 1995theU.S. Geological Survey (USGS) began an intensive investigation of the Norman Landfill plume as part of the USGS Toxic Substances Hydrology Program. These investigations have provided detailed characterization of the sitehydrogeology and plumegeochemistry $(8,22-24)$.

The alluvial aquifer is $10-15 \mathrm{~m}$ thick and consists predominately of quartz sand and silty sand with interbedded mud and gravel. The hydraulic conductivity of the aquifer materials near the landfill ranges from $7.3 \times 10^{-2}$ to $24 \mathrm{~m} /$ day (25). On the basis of water-level data (24) and a hydraulic conductivity of $5.4 \mathrm{~m} /$ day along the flow path, a flow rate of $15.0 \mathrm{~m} / \mathrm{y}$ has been calculated using Darcy's Law. Lowpermeability shalesand siltstones underliethealluvium and act as a boundary to vertical groundwater flow. A shallow 


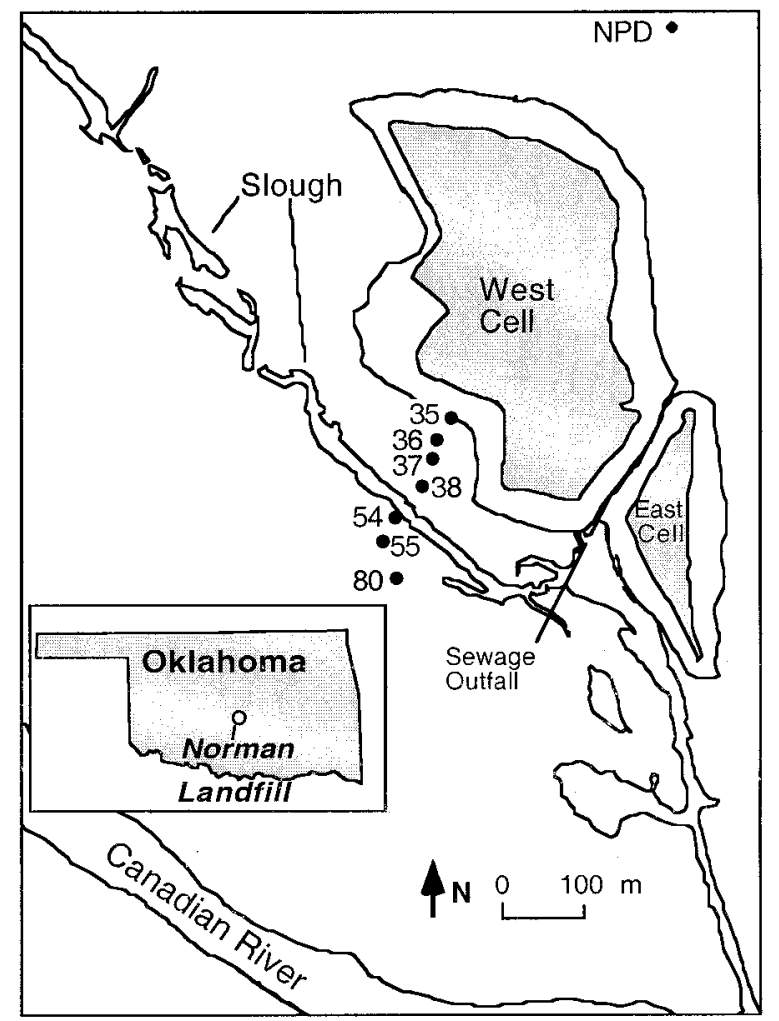

FIGURE 1. Map showing the location of multilevel samplers in the alluvial aquifer adjacent to Norman Landfill. Flow is to the southw est roughly parallel to the samplers. NPD is a background well in the alluvial aquifer.

ephemeral stream (slough) lies parallel to the downgradient side of the landfill and flows into the Canadian River (Figure 1). Our study focuses on the transect from sites 35, 36, 37, $38,54,55$, and 80 (Figure 1) on the southwest side of the landfill. The wells are located parallel to the local flow direction (25).

Groundwater Samplingand Analysis. Water wassampled from permanent multilevel samplers installed along the 3580 transect in 1997 (Figure 1). Each well site contains seven nested wellsconsisting of 2.5-cm PVC pipewith 0.12-m length screens. Six screened intervals were set at roughly $0.5,1.0$, 2.0, 3.0, 4.0, and $7.0 \mathrm{~m}$ depth below the water table at the time of installation. The seventh screen was set just above the base of the alluvium at 11-12 $\mathrm{m}$ depth. Water was pumped with a peristaltic pump. At least two well volumes were pumped before sampling. We sampled for carbon isotopic analyses in June 1998, April 1999, July-August 1999, and December 1999. The waters collected in April 1999 were subject to a comprehensive array of chemical analyses. Sampling and analytical methods for geochemical constituents of groundwater are described in ref 8.

Samples for carbon isotopic analyses of methane were collected in either 25-mL serum bottles (6/98, 7-8/99, 12/ 99) and/or 20-mL vacutainers (4/99). Groundwater was sampled with a syringe attached directly to the pump outlet. Eighteen-mL water samples were injected into evacuated 25-mL serum bottles. Fifteen milliliters of water was injected into the $20-\mathrm{mL}$ vacutainers. Pressures were increased to 1 atm with the addition of purified helium, and $\mathrm{pCO}_{2}$ was reduced by addition of degassed $\mathrm{KOH}$ solution. Samples for dissolved inorganic carbon (DIC $=$ aqueous $\mathrm{CO}_{2}+\mathrm{HCO}_{3}$ $+\mathrm{CO}_{3}=$ ) in groundwater were collected in evacuated $25-\mathrm{mL}$ serum bottles that were filled almost completely. Methane and DIC samples were stored on ice and later refrigerated. Samples were not poisoned. Methane was isotopically analyzed on a Finnigan MAT 252 isotope ratio mass spectrometer (IRMS) with a Varian gas chromatograph interface (GC-C-IRMS). Depending on methane concentration, from 100 to $5000 \mu \mathrm{L}$ of head-gas from the serum bottles were injected into a cryofocusing device that froze methane with liquid nitrogen on mole sieve material. The mole sieve material was heated, and the methane was introduced into the GC-C-IRMS with a helium carrier gas. All measurements were replicated. The precision for $\delta^{13} \mathrm{C}$ of methane based on replicates of samples was $\pm 0.6 \%$. Methane concentrations were determined from mass spectrometer peak areas. Precision was about $\pm 10 \%$. Time series samples were averaged. Chemical variability in these samples sometimes exceeded analytical error, presumably because of vertical chemical gradients.

Data from methane samples collected in manufacturerevacuated vacutainers (4/99) were corrected for background concentrations of methane. This methanehad a $\delta^{13} \mathrm{C}$ of -72.4 $\pm 0.2 \%$ o $(\mathrm{N}=4)$ and yielded a concentration equivalent to $12 \pm 1 \mu \mathrm{M}$ in groundwater. The $\delta^{13} \mathrm{C}$ correction was $0.4 \%$ o or less for samples near the landfill $(>500 \mu \mathrm{M})$ and $2-5 \%$ for downgradient plume samples (89-224 $\mu \mathrm{M})$. Corrections for low-methane samples ( $<10 \mu \mathrm{M}$ after correction) could be large $(>20 \%$ ), but even these corrected values were comparable with $\delta^{13} \mathrm{C}$ values for samples collected in serum bottles at other times.

Groundwater DIC was extracted by injection into an evacuated vessel containing phosphoric acid (16). The evolved $\mathrm{CO}_{2}$ was passed through a dry ice-alcohol slurry to trap water and frozen with liquid nitrogen. A calibrated capacitance manometer was used to measure gas volume, allowing determination of DIC concentration (precision $\approx$ $\pm 5 \%$ ). The $\delta^{13} \mathrm{C}$ of the $\mathrm{CO}_{2}$ was measured on a Finnigan MAT 251 dual inlet IRMS, yielding an overall precision of $\pm 0.1 \%$.

\section{Results and Discussion}

Geochemical Tracers. The Norman Landfill leachate plume is characterized by high concentrations of dissolved organic and inorganic compounds (8). NVDOC within the plume can be as high as $17 \mathrm{mM}$ (Figure 2A), and chloride concentrations can exceed $30 \mathrm{mM}$ (8). The plume also has high alkalinities ( $>40$ mequiv/L) presumably due to the mineralization of organic matter in the landfill. DIC concentrationsmeasured in December 1999(Figure2D) generally approximated DIC values calculated from $\mathrm{pH}$ and alkalinity measurements made in April 1999, indicating that organic acid anions did not contribute significantly to alkalinity. Seepage into the slough resulted in a secondary plume. This "slough plume" was identified by high NVDOC and chloride concentrations (Figure2A(8)). Conservativemixing of plume and background waters is clearly demonstrated from hydrogen isotopic analyses of water. Landfill waters are enriched in deuterium, probably due to methanogenesis (26). Norman Landfill plume waters had $\delta \mathrm{D}$ values greater than $-5 \%$, whereas native groundwaters had values of -30 to $-35 \%$ (27). Unlike $\delta \mathrm{D}, \delta^{18} \mathrm{O}$ of waters varied little within the plume (27). This shows that mixing rather than evaporation controls $\delta \mathrm{D}$.

Geochemical Indicators of Redox Processes. Redoxsensitive compounds within the plume mimic the succession of energy yields for the various microbial reactions. Within the plume core near the landfill, methane was present at high concentrations (up to $1380 \mu \mathrm{M}$ ) but below saturation values (Figure 2E). Methane concentrations decreased above and below the plume and downgradient within the plume. Sulfate concentrations within the plume center were less than $0.02 \mathrm{mM}$ (Figure $2 \mathrm{C}$ ) and increased to $\sim 9$ and $0.4 \mathrm{mM}$ at the upper and lower plume margins, respectively. The high sulfate concentrations at these margins likely reflect reoxidation of iron sulfides produced as a result of sulfate 

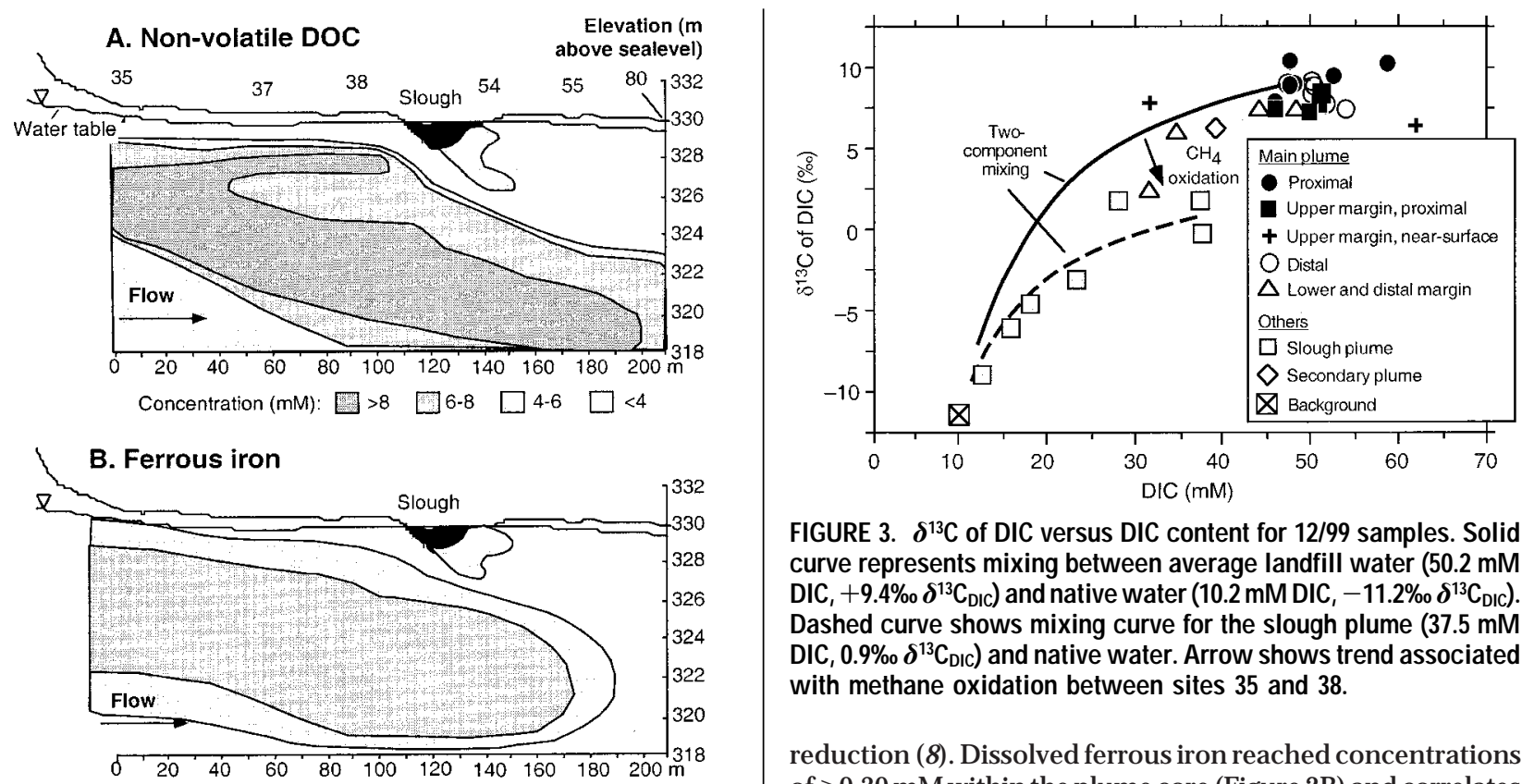

FIGURE 3. $\delta^{13} \mathrm{C}$ of DIC versus DIC content for $12 / 99$ samples. Solid curve represents mixing between average landfill w ater $(50.2 \mathrm{mM}$ DIC, $+9.4 \%{ }_{0} \delta^{13} C_{\text {DIC }}$ ) and native water (10.2 mM DIC, $-11.2 \% 0 \delta^{13} C_{\text {DIC }}$ ). Dashed curve shows mixing curve for the slough plume $(37.5 \mathrm{mM}$ DIC, $0.9 \% \delta^{13} C_{D I C}$ ) and native w ater. Arrow show s trend associated with methane oxidation between sites 35 and 38 .

reduction (8). Dissolved ferrous iron reached concentrations of $>0.30 \mathrm{mM}$ within the plumecore(Figure $2 \mathrm{~B}$ ) and correlates inversely with sulfate. Nitrate was essentially absent $(<0.4$ $\mu \mathrm{M})$ within the plume, and dissolved oxygen was absent throughout almost the entire transect $(<5 \mu \mathrm{M})$ (Figure 2 in ref 8).

Carbon Isotopes in DIC. Carbon isotopic compositions of DIC $\left(\delta^{13} C_{D I C}\right)$ varied from -8.8 to $+10.3 \%$, with the highest $\delta^{13} C_{\text {DIC }}$ values within the plume center (Figure 2D). Such high values $(\geq 8 \%$ o) almost al ways indicate extensive methanogenesis $(15,16)$. The ${ }^{13} \mathrm{C}$-enriched plume waters were also high in DIC concentration and alkalinity. The lowest $\delta^{13} C_{\text {DIC }}$ values $(\leq-5 \%$ ) were found in shallow wells at the downgradient end of the transect. These isotopic compositions approach the $-11.2 \%$ ovalue obtained for a background well (NPD-5) upgradient from thelandfill (8). Such low values are typical of pristine groundwaters. The $\delta^{13} \mathrm{C}$ values of DIC correlate with DIC concentration (Figure 3). To a first approximation, this trend can be explained by mixing between plume waters and native waters. Conservative mixing of these two end-members generates a curved line on a $\delta^{13} \mathrm{C}_{\mathrm{DIC}}$-DIC plot because plume waters are rich in DIC compared with native waters (Figure 3). Slough plume data yield a separate mixing curve. Linear correlation between DIC content and $\delta \mathrm{D}$ of the water (not shown) supports this interpretation. Methane oxidation will add ${ }^{13} \mathrm{C}$-depleted DIC $(-54 \%$ ), which will cause data in Figure 3 to fall below the mixing curve. The effect is minor $(<2 \%$ ), however, because of the low solubility of methane and the large concentration of DIC in plume waters. Oxidation of nonvolatile DOC may have also contributed ${ }^{13} \mathrm{C}$-depleted DIC (around $-25 \%$ ).

Carbon Isotopes in Methane and Methane Oxidation. Carbon isotopic compositions of methane $\left(\delta^{13} \mathrm{C}_{\mathrm{CH}_{4}}\right)$ ranged from -67 to $+28 \%$ o and showed progressive ${ }^{13} \mathrm{C}$ enrichment downgradient within the plume in all four sampling surveys (Figure2E). Near thelandfill, plumemethane had $\delta^{13} \mathrm{C}$ values ranging from -51 to $-56 \%$. The ${ }^{13} \mathrm{C}_{\mathrm{CH}_{4}}$ values within the plume center increased downgradient to about $-30 \%$ o. Over the same interval, methane concentrations decreased from $700 \pm 200 \mu \mathrm{M}$ to $85 \pm 5 \mu \mathrm{M}$. The highest $\delta^{13} \mathrm{C}_{\mathrm{CH}_{4}}$ values were found at the upper and lower margins of the plume, where mixing occurs with less reducing waters.

Declining methane concentrations within the plume can be explained by methane oxidation and by dilution with methane-poor native waters. The increasing $\delta^{13} C_{C_{4}}$ values, however, can best be explained by methane oxidation. We have modeled the plume as a closed system with respect to

FIGURE 2. Distribution of dissolved constituents along the 35-80 transect at the Norman Landfill site. Data are for April 1999 except where noted on figure. (A) nonvolatile DOC, (B) ferrous iron, (C) sulfate, (D) dissolved inorganic carbon (DIC) concentration and $\delta^{13} C$, and (E) methane concentration and $\delta^{13} C$ (average per well). Symbol key for wells is show $n$ in Figures 3 and 4 . Figure $2 A-C$ are modified from ref 8 . 

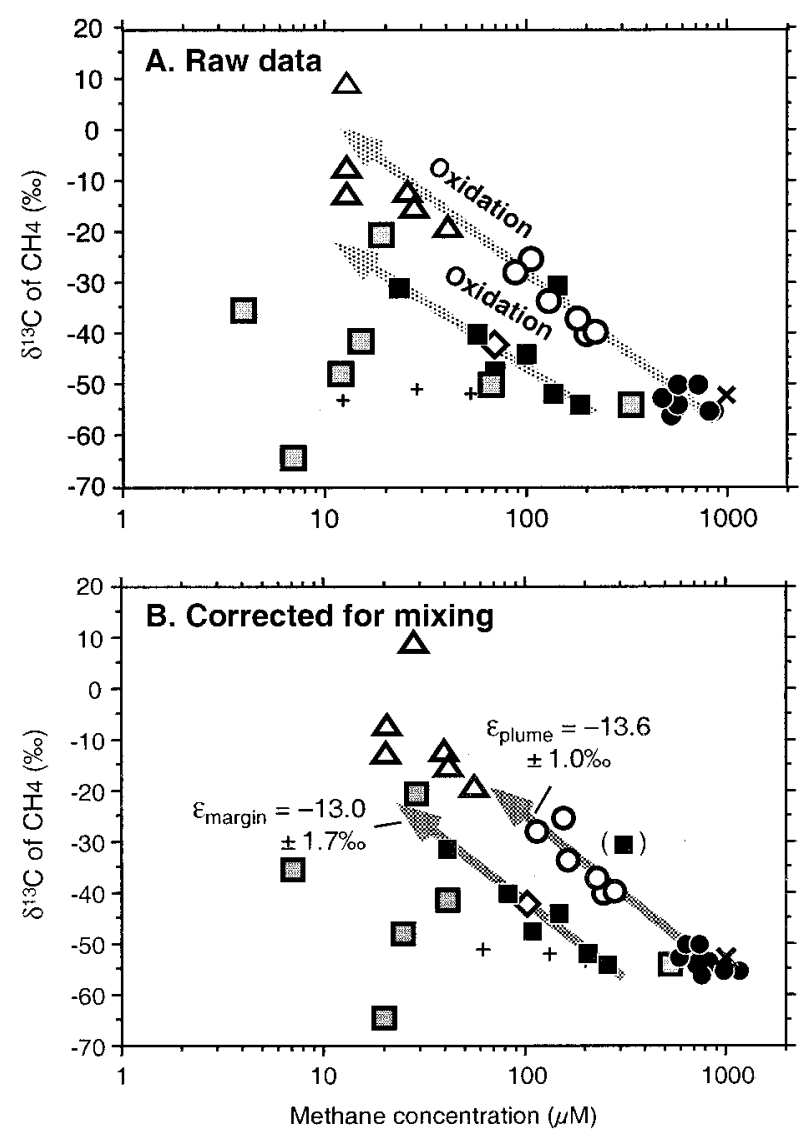

\begin{tabular}{|l|l|}
\hline Main Plume & Others \\
Proximal & Slough plume \\
Upper margin, proximal & $\boldsymbol{\Delta}$ Secondary plume \\
+ Upper margin, near-surface & $\times$ Landfill \\
ODistal & \\
$\Delta$ Lower and distal margin & \\
\hline
\end{tabular}

FIGURE 4. $\delta^{13} \mathrm{C}$ of dissolved methane versus methane concentration for April 1999 transect. Symbols keyed to different parts of the transect. Oxidation of methane in a closed system will yield a straight line on this plot. (A) Raw data. (B) Data corrected for mixing using hydrogen isotopic composition of $w$ ater as a conservative tracer. $\mathrm{CO}_{2}-\mathrm{CH}_{4}$ enrichment factors $\left(\epsilon_{\mathrm{CO}_{2}-}-\mathrm{CH}_{4}\right)$ for methane oxidation (with standard errors) calculated from regressions of plume and upper margin (proximal) data.

methane because methanogenesis and volatilization appear to be unimportant within the plume (see later discussion). Thus, isotopic changes caused by methane oxidation follow the Rayleigh distillation equation

$$
\frac{\mathrm{R}}{\mathrm{R}_{\mathrm{o}}}=\frac{\delta+1000}{\delta_{\mathrm{o}}+1000}=\mathrm{f}^{(\alpha-1)}
$$

where the subscript o indicates initial composition, $\delta=$ $\delta^{13} \mathrm{C}_{\mathrm{CH}_{4}}, \mathrm{R}={ }^{13} \mathrm{C} /{ }^{12} \mathrm{C}$ of methane, $\mathrm{f}=$ fraction of original methane remaining $\left(=\left(\mathrm{CH}_{4}\right) /\left(\mathrm{CH}_{4}\right)_{0}\right)$, and $\alpha=$ the isotopic fractionation factor associated with methane oxidation $\left[=\left({ }^{13} \mathrm{C} /{ }^{12} \mathrm{C}\right)_{\mathrm{CO}_{2} /} /\left({ }^{13} \mathrm{C} /{ }^{12} \mathrm{C}\right)_{\mathrm{CH}_{4}}\right]$. Solving for $\alpha$ yields

$$
\alpha=\frac{\log \frac{\delta+1000}{\delta_{0}+1000}}{\log f}+1=\frac{\log \frac{\delta+1000}{\delta_{0}+1000}}{\log \left[\left(\mathrm{CH}_{4}\right) /\left(\mathrm{CH}_{4}\right)_{0}\right]}+1
$$

On a ${ }^{13} \mathrm{C}_{\mathrm{CH}_{4}}$ versus log $\mathrm{CH}_{4}$ concentration diagram, the trend for methane oxidation approximates a straight line. Figure4A shows results for theApril 1999 transect. The plume and plume margin data define linear trends, suggestive of oxidation. In contrast, near-surface and slough plume samples do not produce a distinct trend. These shallow samples werelikely influenced by variability in initial methane concentration, volatilization, and perhaps aerobic respiration near the water tableand mixing with rain and surface waters.

To determine the isotopic fractionation associated with methane oxidation, methane concentration data must be corrected for mixing. Hydrogen isotopic analyses of water for the April 1999 transect were used to estimate the fraction of native water mixing with landfill water and subsequently the original methane concentration. As with the raw data (Figure $4 \mathrm{~A}$ ), the plot of $\delta^{13} \mathrm{C}_{\mathrm{CH}_{4}}$ versus corrected methane concentration yields two parallel linear trends (Figure 4B). The aberrant plume-margin datum (36-3, in parentheses) is the only plume datum that falls off the $\delta \mathrm{D}$ versus alkalinity plot (figure not shown), suggesting a more complicated history similar to that of near-surface samples. This datum is excluded from regressions. The slopes of the regressions for plumeand margin water data definefractionation factors of $0.9864 \pm 0.0010$ and $0.9870 \pm 0.0017$, respectively. These equateto $\mathrm{CO}_{2}-\mathrm{CH}_{4}$ enrichment factors $\left(\epsilon_{\mathrm{CO}_{2}-\mathrm{CH}_{4}}[\% \mathrm{o}]=1000\right.$ $[\alpha-1])$ of $-13.6 \pm 1.0 \%$ and $-13.0 \pm 1.7 \%$. The two values arestatistically indistinguishableand are within the range of values observed for laboratory experiments with aerobic methanotrophs ( -5 to $-30 \%$; e.g., refs $17-19)$ and for field studies of aerobic methane oxidation in landfill soils $(-8 \%$ o (20); $-22 \%$ o (21)).

The isotopic fractionation associated with anaerobic methaneoxidation is not well constrained. Whiticar and Faber (28) estimated $\epsilon \mathrm{CO}_{2}-\mathrm{CH}_{4}$ values of -2 to $-14 \%$ o based on a compilation of pore-water data from marine and brackish lacustrine sediments. Alperin et al. (29) obtained a value of $-9 \%$ from pore-water profiles of marine sediments. Thus, the fractionation associated with anaerobic methane oxidation at the Norman Landfill site is at the high end of the reported range. For subsequent calculations of methane consumption in the Norman Landfill plume, we will use $-13.6 \%$, the enrichment factor determined for the main plume. Compared with the plume margins, the main plume data are less influenced by surface mixing and consequently yield a regression with less variability.

Our assumption of a closed system within the plume (i.e., no significant methane production and no loss except via oxidation) is supported by geochemical and microbiological data. Volatilization is discounted because dissolved argon concentrations correlate linearly with the $\delta \mathrm{D}$ of the water, indicating that both behaved conservatively. These data also argue against significant oxygen penetration, as that would be accompanied by argon addition. Further evidence against the loss of volatiles in the Norman Landfill plume comes from the relative concentrations and volatilities of volatile organic compounds (23). As for methane production, no $\mathrm{HCO}_{3}{ }^{-}$reduction was detected in sediment slurries from site 35 (adjacent to the landfill), but acetoclastic methanogenesis was detected $(8,30)$. Acetate consumption by methanogenesis was minor compared with acetateoxidation rates presumably by sulfate reduction. Nevertheless, the maximum methane production rates $(\sim 340 \mu \mathrm{M} / \mathrm{y})$ could produce the observed methane concentrations in 3 years. The sediment slurry assays provide localized rates, and their maxima often exceed geochemically derived average rates in aquifers by orders of magnitude (e.g., ref 31). Importantly, sulfate reduction dominates even at site 35, the initial transect site. Downgradient sites are likely to show even less methanogenic activity. Such is the case at a landfill-leachate contaminated aquifer at Grindsted, Denmark, wheresulfate reduction rates greatly exceed methanogenic rates except for wells adjacent to the landfill (7). 


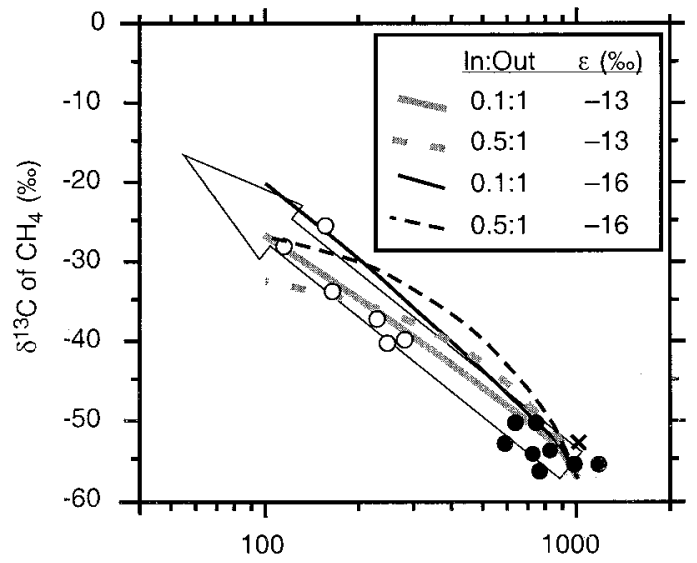

Methane concentration $(\mu \mathrm{M})$

FIGURE 5. $\delta^{13} \mathrm{C}$ of dissolved methane versus methane concentration for April 1999 transect of main plume, corrected for mixing using hydrogen isotopic composition of $w$ ater as a conservative tracer (Figure 4B). Unfilled arrow show s trend for a closed system model with a $\mathrm{CO}_{2}-\mathrm{CH}_{4}$ enrichment factor $(\epsilon)$ of $-13.6 \%$. Curves show trends for different methane production:consumption ratios (in:out (32)). Symbols are defined in Figure 4.

The relation between methane concentration and $\delta^{13} \mathrm{C}$ further supports the assumption of no significant methane production. We used the mass transfer model of Wigley et al. (32) to model the isotopic effects of concurrent methane production and consumption (presumably in different microzones). Themodel was run with production:consumption ratios of $0.1: 1$ and $0.5: 1$ and $\mathrm{CO}_{2}-\mathrm{CH}_{4}$ enrichment factors of $-13 \%$ ond $-16 \%$ (Figure 5). These parameters were chosen because they produced results that overlap theobserved data for the main plume. The $0.1: 1$ model with $\epsilon=-13 \%$ yields a curve close to the line for a closed system model with $\epsilon=$ $-13.6 \%$, indicating that minor production did not greatly influence the determination of $\epsilon$. The $0.5: 1$ models produce results that deviate sufficiently from the data trend to argue against significant production of methanealong the transect.

Distribution and Rates of Anaerobic MethaneOxidation. Theoretically, the fraction of methane oxidized in a given sample can be calculated based on the carbon isotopic composition of the methane, regardless of the original concentration or the degree of dilution. Solving eq 2 for log $\mathrm{f}$ yields

$$
\log f=\frac{\log _{\delta_{o}+1000} \delta+1000}{\alpha-1}
$$

The percent methane oxidized equals $100(1-f)$. This equation assumes that $\alpha$, derived from data from the plume transect, was constant. Figure 6 shows the percent methane oxidized along the 35-80 transect. At least $84 \%$ of the methane was oxidized in the 14 years it took the plume to travel the length of the $210-\mathrm{m}$ transect. We could have calculated fraction of methane oxidized from the methane concentrations corrected for dilution using $\delta \mathrm{D}$ data for water; however, those data are only availablefor theApril 99 samples. Furthermore, the methodology described here has more general application because it provides a test for concurrent methane production in microenvironments and is independent of original methane concentration, which can vary (Figure 4).

Previous studies used first-order kinetics to describe anaerobic methane oxidation. Iverson et al. (33) found that the rate of anaerobic methane oxidation in Big Soda Lake was proportional to methane concentration and did not level

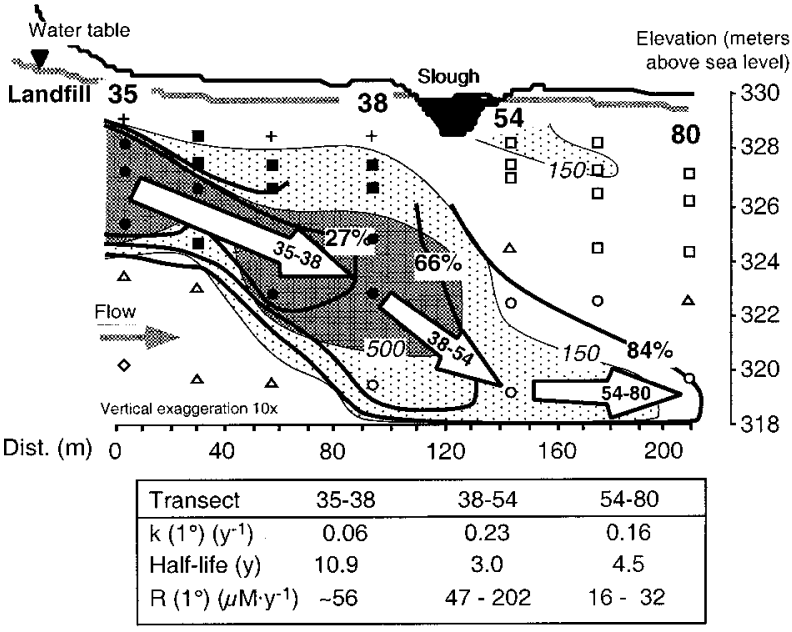

FIGURE 6. 35-80 transect w ith contours for methane content (italics) and percentmethane oxidized (bold; from $\delta^{13} \mathrm{C}$ contours). Also show $\mathrm{n}$ are the three segments modeled for anaerobic methane oxidation rates and the rate constants, half-lives, and rates.

off even at the highest concentrations examined (about 50 $\mu \mathrm{M})$. In a study of nitrate reduction, Smith et al. (12) found that methane oxidation in a Cape Cod aquifer was dependent upon methane concentration at concentrations up to 6-9 $\mu \mathrm{M}$ and oxidation rates of $\sim 150 \mu \mathrm{M} / \mathrm{y}\left(\mathrm{V}_{\text {max }}\right)$. Aswill beshown later, this rate is greater than all but the most extreme values obtained here. The first-order rate equation is $\mathrm{d}\left(\mathrm{CH}_{4}\right) / \mathrm{dt}=$ $-\mathrm{k}\left(\mathrm{CH}_{4}\right)$, wheret $=$ timeand $\mathrm{k}=$ thefirst-order rate constant. The rate constant equals

$$
k=-2.303 \frac{\log \left[\left(\mathrm{CH}_{4}\right) /\left(\mathrm{CH}_{4}\right)_{\mathrm{o}}\right]}{t}=-\frac{2.303 \log \mathrm{f}}{\mathrm{t}}
$$

We calculated $k$ for three segments of the plume along the 35-80 transect (Figure 6). For each segment, $f$ was determined from eq 3 and the methane $\delta^{13} \mathrm{C}$ at the beginning and end of the segments. Time $t$ for each segment was calculated from flow rate and distance. The rate constants for oxidation vary from 0.06 to $0.23 y^{-1}$, which yield half-lives for methane of 3 to $12 \mathrm{y}$. The $0.23 \mathrm{y}^{-1}$ value is almost identical to that obtained in anoxic culture experiments with water from Big Soda Lake $\left(0.20 \mathrm{y}^{-1}(33)\right)$. Rates calculated from rate constants and concentrations vary from $18 \mu \mathrm{M} \cdot \mathrm{y}^{-1}$ in the far reaches of the transect (site 80 ) to $230 \mu \mathrm{M} \cdot \mathrm{y}^{-1}$ in the midsection of the plume where methane content is high. The variation in rate constant shows that an additional factor besides methane concentration controls methane oxidation. Availability of electron acceptors (such as $\mathrm{SO}_{4}{ }^{2-}$ ) and (or) microbial abundance and activity probably also control anaerobic oxidation rates. Sulfate concentration was very low $(<0.12 \mu \mathrm{M})$ within the plume center, but Barite dissolution may have provided slow release of sulfate (see later discussion).

Methaneoxidation rates in the leachate plumeat Norman Landfill are 3 orders of magnitude lower than aerobic methane oxidation rates in waterlogged landfill cover soils from the Berkeley North Waterfront Park site ((34) Figure 7). Aerobic oxidation is a far more efficient sink for landfill methane than anaerobic oxidation; however, the low solubility of molecular oxygen causes it to be a minor electron acceptor within contaminated aquifers. At the Norman Landfill site, aerobic methane oxidation may occur near the water table, but methanotrophs have to compete with sulfur, iron, and ammonia oxidizers for oxygen. Alternatively, Fe(III) and nitrate may serve as electron acceptors for methane oxidation near the water table. 


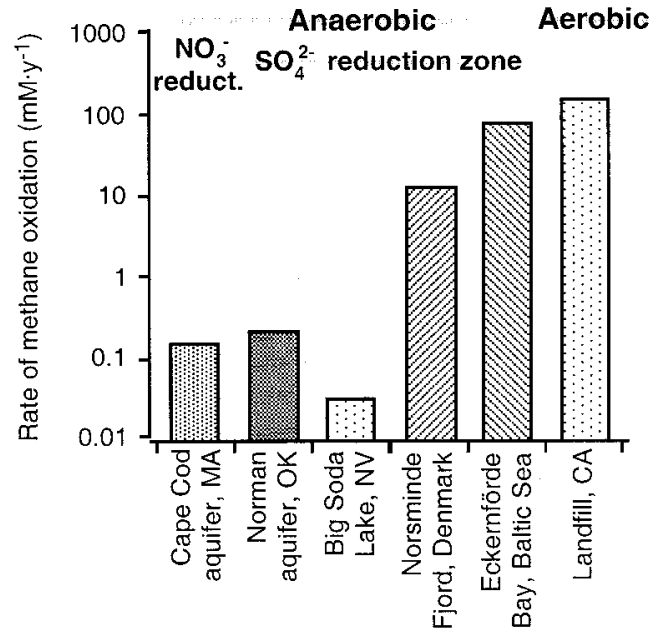

FIGURE 7. Maximum rates of anaerobic methane oxidation in the Norman leachate plume, Cape Cod aquifer (12), Big Soda Lake (33), Norsminde Fjord (35), and Eckernforde Bay (36). Also show $n$ is a rate for aerobic methane oxidation in a water-saturated landfill soil in California (34).

The anaerobic methane oxidation rates observed at Norman Landfill are of the sameorder of magnitudeas those in two other terrestrial systems (Figure 7). Natural-gradient tracer tests in a Cape Cod aquifer, using nitrate as an electron acceptor, yielded anaerobic oxidation rates of $150 \mu \mathrm{M} / \mathrm{y}$ (12). Anaerobic methane oxidation rates in the sulfate-reducing zone of Big Soda Lake, NV, were found to be $18-31 \mu \mathrm{M} / \mathrm{y}$ (33). In contrast, anaerobic methane oxidation associated with sulfate reduction in marine sediments (35) and sediments within a marine-groundwater mixing zone (36) progresses at rates that are 1-3 orders of magnitude greater (6200-72 $000 \mu \mathrm{M} / \mathrm{y}$ ) compared with terrestrial systems. The cause of these different rates, whether reflecting availability of electron acceptors, availability of other electron donors, or the composition or activity of the microbial community, is a fruitful area for future study.

The mechanism for anaerobic methane oxidation in sulfate-reducing zones is hotly debated. Numerous studies have contended that sulfate-reducing bacteria (SRB) use methaneas an electron donor, but no SRB have been cultured that can mediate the process. Relatively recent studies have proposed that anaerobic methane oxidation is the result of a consortium of Archaea and SRB $(37,38)$. Laboratory studies suggest that SRB lower $\mathrm{H}_{2}$ concentrations to the point where reverse $\mathrm{CO}_{2}$ reduction by methanogens becomes thermodynamically favorable (37). Methanogens have also been shown to oxidize methane through reverse acetate dissimilation (39), and recently an acetogenic reaction involving oxidation of methane by water has been proposed (40).

Microbiological studies at Norman Landfill site 35 (8) support an association between sulfate reduction and methane oxidation. Despite low sulfateconcentrations within the plume center, sulfate reduction activity is relatively high (3.5 $\mu \mathrm{M} \mathrm{SO}_{4}{ }^{2-} /$ day). In contrast, microbial Fe(III) reduction was detected only in the upper and lower margins of the plume. Dissolution of barite may providea slow, continuous source of sulfate within the plume $(8,41)$. Barite was found within the aquifer and dissolved barium concentrations of up to $100 \mu \mathrm{M}$ were measured within the plume. Thus, our results support the contention that anaerobic methane oxidation associated with sulfate reduction occurs in aquifer systems. This hasimportant implicationsfor biogeochemical processes in landfills and the environmental impact of these sites. Natural attenuation of priority pollutants at landfills depends on the availability of electron acceptors. The consumption of electron acceptors during methane oxidation could significantly impact the long-term sustainability of natural attenuation of other contaminants of concern. In addition, anaerobic methane oxidation needs to be considered when predicting the contribution that old landfills, like the Norman Landfill, may play in releasing this important greenhouse gas to the atmosphere.

\section{Acknowledgments}

This project was conducted as part of the U.S. Geological Survey Toxic Substances Hydrology Research Program. We thank Steven Harris for assistance with sampling, Jeanne Jaeschke for analytical support, and George Breit, Robert Eganhouse, Steven Harris, Joseph Suflita, Michelle Tuttle, and Glenn Ulrich for helpful discussions. We appreciate careful reviews by USGS reviewers J. K. Bohlke, Francis Chapelle, and Laurence Miller and four anonymous reviewers. Finally, wethank Scott Christenson for logistical support throughout the duration of the project. The use of brand, trade, firm, or company names in this paper is for identification purposed only and does not constitute endorsement by the U.S. Geological Survey.

\section{Literature Cited}

(1) Glenn, J. BioCycle 1998, April, 32-43.

(2) U.S. EPA. U.S. Methane Emissions 1990-2020: Inventories, Projections, and Opportunities for Reductions; EPA 430-R-99013; Environmental Protection Agency, Office of Air and Radiation: 1999.

(3) Bogner, J. E.; Spokas, K. A.; Burton, E. A. Environ. Sci. Technol 1997, 31, 2505-2514.

(4) Williams, G. M.; Ward, R. S.; Noy, D. J. WasteManage. Res. 1999, $17,327-342$.

(5) Baedecker, M. J.; Back, W. Ground Water 1979, 17, 429-437.

(6) Lyngkilde, J.; Christensen, T. H. J. Contam. Hydrol. 1992a, 10, 273-289.

(7) Ludvigsen, L.; Albrechtsen, H.-J.; Heron, G.; Bjerg, P. L.; Christensen, T. H. J. Contam. Hydrol. 1998, 33, 271-291.

(8) Cozzarelli, I. M.; Suflita, J. M.; Ulrich, G. A.; Harris, S. H.; Scholl, M. A.; Schlottmann, J. L.; Christenson, S. Environ. Sci. Technol. 2000, 34, 4025-4033.

(9) Lyngkilde, J.; Christensen, T. H. J. Contam. Hydrol. 1992b, 10, 291-307.

(10) Rügge, K.; Bjerg, P. L.; Christensen, T. H. Environ. Sci. Technol. 1995, 29, 1395-1400

(11) Bjerg, P. L.; Rügge, K.; Pedersen, J. K.; Christensen, T. H. Environ. Sci. Technol. 1995, 29, 1387-1394.

(12) Smith, R. L.; Howes, B. L.; Garabedian, S. P. Appl. Environ. Microbiol. 1991, 57, 1997-2004.

(13) Zhang, C.; Grossman, E. L.; Ammerman, J. W. Ground Water 1998, 36, 58-66.

(14) Kelly, W. R.; Matisoff, G.; Fisher, J. B. Environ. Geol. Water Sci 1985, 7, 205-213.

(15) Whiticar, M. J. Chem. Geol. 1999, 161, 291-314.

(16) Grossman, E. L. In Manual of Environmental Microbiology, 2nd ed.; Hurst, C. J., et al. Eds.; American Society for Microbiology Press: Washington, DC, 2002.

(17) Barker, J. F.; Fritz, P. Nature 1981, 293, 289-291.

(18) Coleman, D. D.; Risatti, J. B.; Schoell, M. Geochim. Cosmochim. Acta 1981, 45, 1033-1037.

(19) Zyakun, A. M.; Bondar, V. A.; Nammsaraev, B. B. Freiberger Forsch. 1981, 360, 19-27.

(20) Bergamaschi, P.; Lubina, C.; Königstedt, R.; Fischer, H.; Veltkamp, A. C.; Zwaagstra, O. J. Geophys. Res. 1998, 103, 8251-8265.

(21) Liptay, K.; Chanton, J.; Czepiel, P.; Mosher, B. J. Geophys. Res. 1998, 103, 8243-8250.

(22) Christenson, S.; Scholl, M. A.; Schlottmann, J. L.; Becker, C. J. U.S. Geological Survey Toxic Substances Hydrology Program, Proceedings of the Technical Meeting, Charleston, SC, March 8-12, 1999-Vol. 3, SubsurfaceContamination from Point Sources; Water-Resources Investigations Report 99-4018C; M organwalp, D. W., Buxton, H. T., Eds.; U.S. Geological Survey: West Trenton, NJ, 1999.

(23) Eganhouse, R. P.; Cozzarelli, I. M.; Scholl, M. A.; Matthews, L. L. Ground Water 2001, 39, 192-202.

(24) Scholl, M. A.; Cozzarelli, I. M.; Christenson, S. C.; Breit, G. N.; Schlottmann, J. L. U.S. Geological Survey Toxic Substances Hydrology Program, Proceedings of the Technical Meeting, Charleston, SC, March 8-12, 1999-Vol. 3, Subsurface Contami- 
nation from Point Sources; Water-Resources Investigations Report 99-4018C; Morganwalp, D. W., Buxton, H. T., Eds.; U.S. Geological Survey: West Trenton, NJ, 1999; pp 557-568.

(25) Scholl, M. A.; Christenson, S. Water-Resources Investigations Report 97-4292; U.S. Geological Survey: Oklahoma City, OK, 1998; $28 \mathrm{pp}$.

(26) Hackley, K. C.; Liu, C. L.; Coleman, D. D. Ground Water 1996 34, 827-836.

(27) Schlottmann, J. L. Water-Resources Investigations Report 004238; U.S. Geological Survey: Oklahoma City, OK, 2000; 44 pp.

(28) Whiticar, M. J.; Faber, E. Org. Geochem. 1986, 10, 759-768.

(29) Alperin, M.J.; Reeburgh, W. S.; Whiticar, M.J. Global Biogeochem. Cycles 1988, 2, 279-288.

(30) Harris, S. H.; Ulrich, G. A.; Suflita, J. M. U.S. Geological Survey Toxic Substances Hydrology Program, Proceedings of the Technical Meeting, Charleston, SC, March 8-12, 1999-Vol. 3, Subsurface Contamination from Point Sources; M organwalp, D. W., Buxton, H. T., Eds.; Water-Resources Investigations Report 99-4018C; U.S. Geological Survey: West Trenton, NJ, 1999; pp 541-548.

(31) Jakobsen, R.; Postma, D. Geology 1994, 22, 1103-1106.

(32) Wigley, T. M. L.; Plummer, L. N.; Pearson, F. J., Jr. Geochim. Cosmochim. Acta 1978, 42, 1117-1139.

(33) Iverson, N.; Oremland, R. S.; Klug, M. J. Limnol. Oceanogr. 1987, $32,804-814$.
(34) Whelen, S. C.; Reeburgh, W. S.; Sandbeck, K. A. Appl. Environ. Microbiol. 1990, 56, 3405-3411.

(35) Hansen, L. B.; Finster, K.; Fossing, H.; Iverson, N. Aquatic Microbial Ecol. 1998, 14, 195-204.

(36) Bussmann, I.; Dando, P. R.; Niven, S. J.; Suess, E. MarineEcology Progress Ser. 1999, 178, 169-177.

(37) Hoehler, T. M.; Alperin, M.J.; Albert, D. B.; Martens, C. S. Global Geochem. Cycles 1994, 8, 451-463.

(38) Boetius, A.; Ravenschlag, K.; Schubert, C. J.; Rickert, D.; Widdel, F.; Gieseke, A.; Amann, R.; Jorgensen, B. B.; Witte, U.; Pfannkuche, O. Nature 2000, 407, 623-626.

(39) Zehnder, A. J. B.; Brock, T. D. J. Bacteriol. 1980, 137, 420-432.

(40) Valentine, D. L.; Reeburgh, W. S. Environ. Microbiol. 2000, 2, 477-484.

(41) Tuttle, M. L.; Breit, G. N.; Cozzarelli, I. M.; Harris, S. H. Geological Society of America Abstracts with Programs; 2000 GSA Annual Meeting, Reno, NV, 2000; p A127.

Received for review September 13, 2001. Revised manuscript received February 27, 2002. Accepted March 25, 2002. 